\title{
A STUDY OF LIVER FUNCTION AND PLASMA VOLUME IN CHRONIC RHEUMATISM BY MEANS OF PHENOL-TETRABROM-PHTHALEIN SODIUM SULPHONATE*
}

\author{
By G. L. ROBINSON \\ (From the Research Laboratory of the Devonshire Royal Hospital, \\ Buxton.)
}

\section{INTRODUCTION}

THE idea that the tendency to develop arthritic disease is " undoubtedly a hepatic deficiency" (Bezançon and Weil, 1938) not only still persists but has gained some support from the laboratory. Two reports (both labelled preliminary, though both devoid of issue) have described hepatic function among assortments of chronic rheumatics as impaired: one author (Watson, 1928) used a salicylate excretion test, while the other (Miller, 1935) estimated lævulose tolerance. In the case of rheumatoid arthritis only, a decreased tolerance for glucose has been remarked more than once, and a recent determination (Andrews and Muether, 1941) of the arteriovenous difference of blood-glucose level in this disease discounts any explanation in terms of accelerated blood flow, favouring an actual fall in the glycogenic power of the liver, which might, however, be either hepatic or endocrine in origin. An investigation of liver function (Rawls, Weiss and Collins, 1939), in which intravenously injected azorubin was recovered by duodenal tube, resulted in 60 per cent. abnormal excretions among fifty unselected cases of rheumatoid arthritis. This abnormality was held to lie not always in delayed, but sometimes in accelerated transference of dye into the bile. On the clinical side, a collection has been made (Hench, 1938-40) of over seventy cases of "atrophic arthritis" and "primary fibrositis" in which the chance concurrence of jaundice caused dramatic though temporary remissions of rheumatic symptoms. This appears to contradict the foregoing results, and might even be interpreted to mean that the rheumatic liver is over-efficient, a state of affairs also suggested by those " abnormal" azorubin excretions which were accelerated. Again, the blood protein in rheumatoid arthritis is raised, whilst in liver deficiency it is lowered. The finding of raised blood volumes by the Congo red method (Sparks and Haden, 1932) in twenty-six cases of rheumatoid arthritis might also be made to fit a picture of hepatic hyperfunction by assuming that the dye

* Based on a thesis for the degree of M.D. (University of Cambridge), by permission of the Regius Professor of Medicine. 
had not been overdiluted by excess of plasma, but removed by overactive Kupffer cells. In the present work, the liver test dye phenoltetrabrom-phthalein sodium sulphonate (" bromsulphalein ") has been used in such a way as to throw some light both on liver function and on plasma volume in chronic rheumatism.

\section{Technical Procedure}

Preliminary experiments established the following points: (1) that bromsulphalein added in vitro to the blood of normal or rheumatoid subjects does not enter the red corpuscles; (2) that bromsulphalein is removed from plasma with the protein in the Folin-Wu, but remains with the liquid in alcohol or acetone precipitation; (3) that bromsulphalein dissolved in plasma will not pass a collodion membrane in four days, but dissolved in saline or 5 per cent. peptone will diffuse at once, reaching equilibrium in about twelve hours; (4) that solutions of bromsulphalein in dilute ammonia give a well defined absorption band, centred at $583 \mathrm{~m} \mu$, when examined in a Hilger spectrophotometer.

The following method was developed to extract the dye, free from opacities and protein, from blood samples for spectrophotometric estimation. To $3 \mathrm{ml}$. distilled water in a 15-ml. contrifuge tube add $8 \mathrm{ml}$. acetone and invert to mix, then $1 \mathrm{ml}$. plasma and invert three times. Centrifuge 3 to 4 minutes at 2 to 3 thousand revolutions per minute. With a 9-ml. pipette, the tip just above packed precipitate, withdraw $9 \mathrm{ml}$. fluid by sucking steadily to above mark and draining down. Run this fluid into a similar tube containing $1 \mathrm{ml}$. distilled water, add $2 \mathrm{ml}$. chloroform, stopper by thumb and give about fifty vigorous horizontal shakes. Centrifuge as before. Transfer the whole supernatant layer by teat pipette to $20-\mathrm{ml}$. volumetric flask. Dilute with distilled water, add $1 \mathrm{ml} \cdot \cdot 880$ ammonia, then dilute to mark with distilled water and mix well. Read in a 10-cm. cell (15-ml. capacity) in the spectrophotometer from half to one hour later. The formula, determined by plotting known concentrations of dye in plasma, is:

$$
x=3 \cdot 5(\mathrm{D}-0 \cdot 25) \text {, }
$$

where $x$ is the plasma concentration of dye in $\mathrm{mg}$. per $100 \mathrm{ml}$. and $\mathrm{D}$ is the extinction coefficient at $583 \mathrm{~m} \mu$ read directly on the scale.

It was now possible to follow the fate of intravenously injected dye by repeated sampling at short intervals, thus producing bromsulphalein tolerance curves (Fig. 1) which showed maxima at 1.25 minutes after injection and a slowing of the initially uniform removal rate after about six minutes. A three-sample procedure was therefore adopted as standard for the clinical side of the testing: the first sample to give the peak value attained at 1.25 minutes, the second at 2.5 minutes to fix the initial rate of fall where the graph is rectilinear 
and steep, the third at $\mathbf{7 . 2 5}$ minutes for estimation of the removal rate over the whole sensitive period before the rate becomes slow.

After a gentle walk of about two minutes, the patient is seated beside a table in such a position that either arm can be laid across the corner of it in comfort. An accurate syringe is then charged with the required dose $(3.5 \mathrm{mg}$. per $\mathrm{kg}$. body weight was used in the present work) of 5 per cent. solution of bromsulphalein, and three other syringes (5 or $10 \mathrm{ml}$.) are prepared by rinsing with sterile saline and laid ready in a row on the table, the first only bearing a SWG 20 needle, while the third contains $1 \mathrm{ml}$. sterile saline. A watch with a seconds hand and three 5-ml. centrifuge tubes, each containing one drop of saturated potassium oxalate solution, are also placed handy. The injection of the dye is made to last for a period of $25 \pm 5$ seconds after release of the tourniquet on entering the vein, and the arm subsequently held raised for one minute and then lowered into the lap. As soon as the injection is over, the other arm is placed upon the table, tourniquet applied, vein entered and tourniquet released, this process being completed in well under 30 seconds. At exactly one minute after the end of the injection blood is drawn into the syringe at such a pace that $5 \mathrm{ml}$. are obtained in 30 seconds, the average timing of this sample being therefore 1.25 minutes. The syringe is then de-

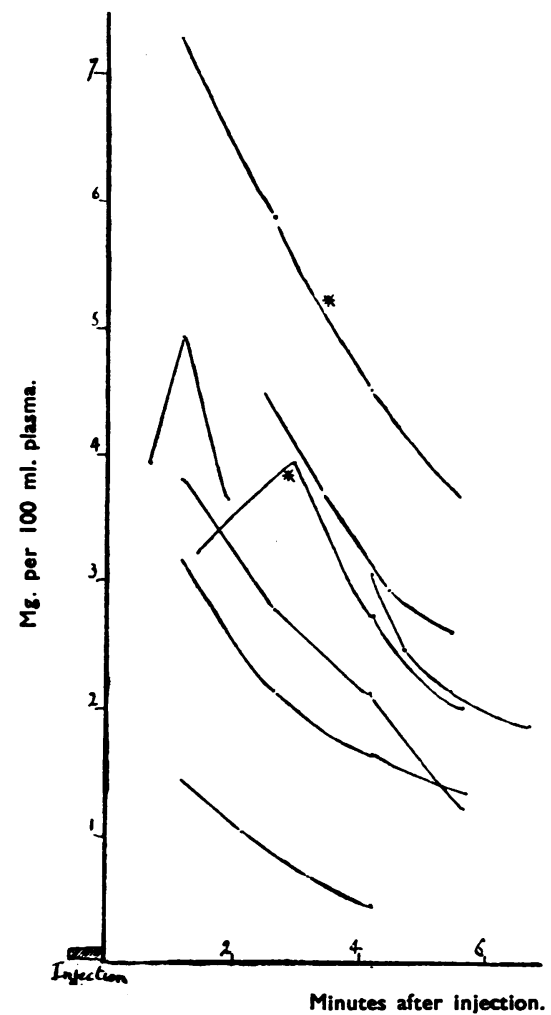

Fig. 1.-Eight Tolerance Curves OBTATNED From VARIOUS SUBJECTS USING VARIOUS Doses aND SAMPLE Times. tached, handed to the assistant, who ejects the blood into the first oxalated tube and mixes it, and the second syringe is fitted to the needle. The second sample is drawn in the same way from 2.25 to 2.75 minutes, being therefore timed at 2.50 minutes after the end of the injection. On attaching the third syringe to the needle, $1 \mathrm{ml}$. sterile saline is injected from it into the vein in order to prevent clotting in the needle during the longer wait until the third sample, timed at $7 \cdot 25$ minutes, is drawn.

In order to calculate the plasma volume by this method, it is assumed that the same amount of dye is removed during the first 1.25 minutes after the end of injection as during the second, which figure is given 
by the difference in concentration between first and second samples. In other words, the steep straight line of the early part of the tolerance curve is produced backwards to cut the ordinate at a concentration which would have been attained had not the dye been undergoing removal at the determined rate. Plasma volume is then found by dividing this theoretical maximum concentration (mg. per $100 \mathrm{ml}$.) into one hundred times the weight (mg.) of dye administered. It will be seen from ensuing tables that absolute values found for normals are not much below the orthodox $50 \mathrm{ml}$. plasma per kg. body weight given by most dye tests of blood volume and assumed in calibration of the comparator tubes used in the ordinary bromsulphalein test of liver function (Rosenthal and White, 1925).

No ill effects of any kind were ever observed to follow intravenous injection of bromsulphalein.

\section{Discussion of Procedure}

A certain number of subjects exhibited " delayed " curves in which the concentration of dye in the second sample equalled or even exceeded that in the first. Such results did not occur with cases treated in bed or sitting in wheeled chairs, but they seemed to come particularly from those ambulant subjects who had waited for some time before being tested. It was only towards the end of the series that the preliminary two-minute stroll was adopted, eliminating further anomalies; thus a number of delayed curves are included in the tables below, in which, in the absence of a peak concentration at 1.25 minutes, no calculation of plasma volume was possible, and in which dye retention could only be determined over the 4.75 minute period between second and third samples. A delayed curve is shown, marked with an asterisk, in Fig. 1, the other curve so marked being from the same subject (a healthy engine-driver aged 54 suffering from sciatica) using a 1.5 times larger dose of dye one week later.

To express numerically the ability of the liver to remove dye from the circulation it is not enough simply to measure the crude removal rate in $\mathrm{mg}$. per $100 \mathrm{ml}$., for this rate varies with the concentration of dye in the plasma, as is shown by comparing the slopes of the uppermost and lowermost curves in Fig. 1. In theory, the concentrations of dye in the plasma of different subjects can be equated by the use of a dosage proportional to body weight; but in practice, particularly in the diseased, plasma volume is not always paralleled by body weight. It is perhaps because these two factors (i.e., dependence of removal rate on concentration and lack of constant relation between plasma volume and body weight) act in opposition to each other that they have been neglected in the orthodox bromsulphalein test; but variation in the hepatic removal rate of dye is not of such a degree as rapidly to equate varying concentrations in the blood stream. 
Therefore in this work the "index of hepatic efficiency" has been obtained by expressing the rate of removal (mg. per $100 \mathrm{ml}$. per min.) as a percentage of the concentration of dye in the plasma (mg. per $100 \mathrm{ml}$.) at the beginning of the period over which removal rate is measured. In order to include delayed curves, this index has been calculated for the period between second and third samples ( 4.75 mins.) as well as for that between first and third (6 mins.).

\section{TaBles of Regults}

The data obtained by testing are set out in eleven numbered columns in a series of tables.

Column 1 gives the age of the subject in years.

Column 2 gives the weight of the subject in $\mathrm{kg}$.

Column 3 gives the suspension stability of the blood. The figure expresses the percentage of the blood volume occupied by the red cells at the end of one hour's sedimenting of $5 \mathrm{ml}$. oxalated blood in a centrifuge tube. The method has been adopted as standard by several rheumatic hospitals (Collins et al., 1939).

Column 4 gives the percentage of the blood volume occupied by the packed red cells.

Column 5 gives the plasma protein percentage, estimated by the Kjeldahl method.

Column 6 gives the plasma volume in ml. per kg. body weight, obtained by the bromsulphalein method.

Column 7 gives the blood volume in $\mathrm{ml}$. per $\mathrm{kg}$. body weight.

Column 8 gives the removal rate of bromsulphalein from the blood stream in mg. per $100 \mathrm{ml}$. per minute, over a 6-minute interval from 1.25 to 7.25 minutes after injection.

Column 9 gives the 6-minute index of hepatic efficiency, obtained by expressing the 6-minute removal rate as a percentage of the dye concentration in the first sample.

Column 10 gives the removal rate over a 4.75 minute interval from 2.5 to $7 \cdot 25$ minutes after injection.

Column 11 gives the 4.75 minute index of hepatic efficiency-i.e., the 4.75 minute rate expressed as percentage of dye concentration in the second sample.

Table I comprises the results obtained with thirteen female controls by the three-sample procedure and the acetone extraction, using a dose of $3.5 \mathrm{mg}$. per $\mathrm{kg}$. body weight. It will be seen that these cases are anæmic, with a packed red cell volume averaging only 37 per cent., whereas the normal figure for oxalated female blood is 42 per cent. (Collins et al., 1939). This anæmia is that of the "hospital class," related to income rather than minor rheumatic trouble: number 76, for instance, attending for massage with a healed laceration of the fore-arm, shows no less anæmia than the rest. 
TABLE I

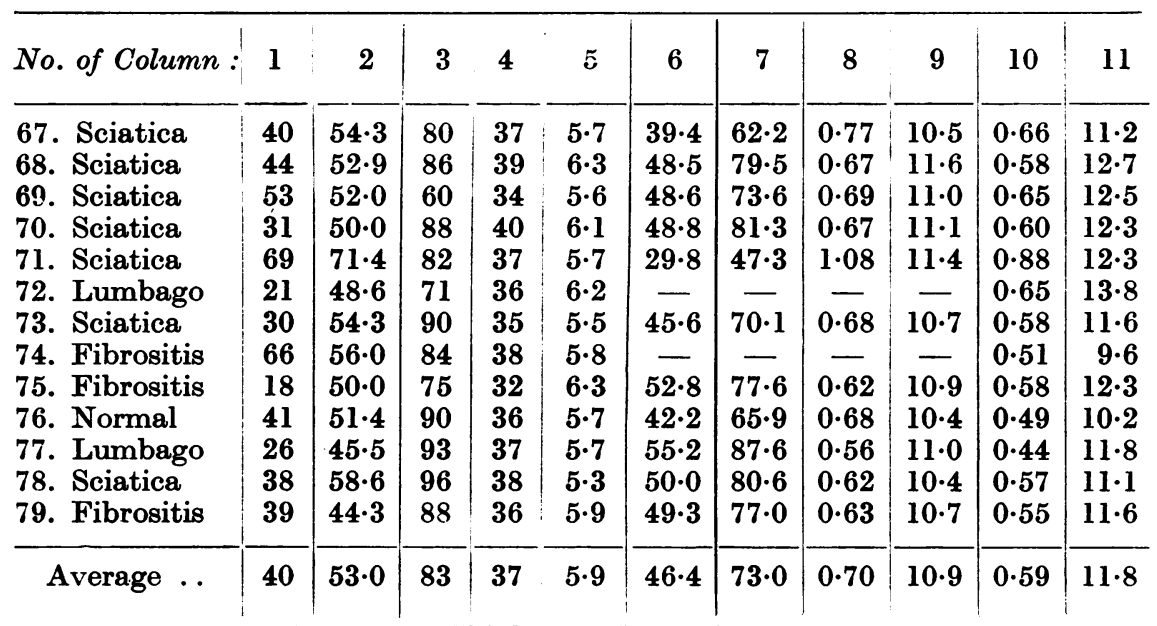

Table II.-Findings in Twenty-one Female Cases of Rheumatoid Arthritis (Two Repeats being INCluded) Which were Selacted as Typical of the Disease.

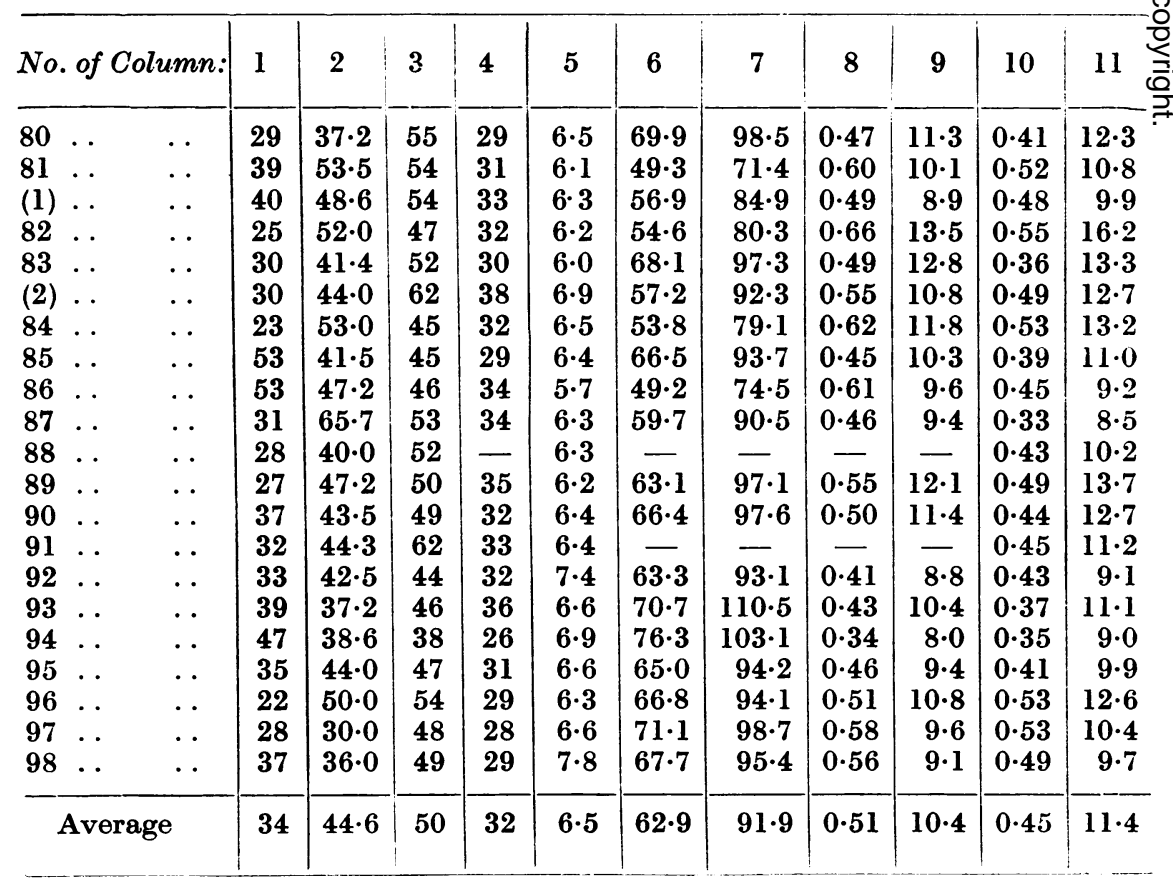

(1) Same subject as 81, worse, 1 year later.

(2) Same subject as 83 , improved, 5 weeks later. 
Twenty-four male controls are listed in Table III, 8 cases of typical subacute rheumatism in Table IV.

TABLE III

\begin{tabular}{|c|c|c|c|c|c|c|c|c|c|c|c|}
\hline No. of Column & 1 & 2 & 3 & 4 & 5 & 6 & 7 & 8 & 9 & 10 & 11 \\
\hline 99. Sciatica & 33 & $60 \cdot 0$ & 88 & 38 & $5 \cdot 8$ & $51 \cdot 7$ & $83 \cdot 4$ & 0.57 & $12 \cdot 0$ & 0.45 & $14 \cdot 5$ \\
\hline 100. Sciatica & 63 & $61 \cdot 4$ & 74 & 35 & $5 \cdot 5$ & $\mathbf{5 3} \cdot 5$ & $82 \cdot 3$ & 0.65 & $11 \cdot 4$ & 0.64 & $13 \cdot 2$ \\
\hline 101. Sciatica & 52 & $64 \cdot 3$ & 68 & 34 & $5 \cdot 9$ & $41 \cdot 1$ & $62 \cdot 3$ & $0 \cdot 86$ & $12 \cdot 7$ & $0 \cdot 72$ & $14 \cdot 2$ \\
\hline 102. Sciatica & 39 & $70 \cdot 0$ & 83 & 38 & $6 \cdot 3$ & $52 \cdot 6$ & $\mathbf{8 4 \cdot 8}$ & 0.65 & $11 \cdot 6$ & 0.60 & $13 \cdot 2$ \\
\hline 103. Sciatica & 30 & $60 \cdot 0$ & 97 & 41 & $5 \cdot 3$ & $48 \cdot 7$ & $82 \cdot 6$ & 0.70 & $11 \cdot 6$ & $0 \cdot 64$ & $13 \cdot 2$ \\
\hline 104. Sciatica & 35 & $68 \cdot 6$ & 97 & 41 & $5 \cdot 6$ & 43.1 & $73 \cdot 0$ & 0.74 & $11 \cdot 6$ & 0.57 & $12 \cdot 3$ \\
\hline 105. Sciatica & 40 & $63 \cdot 0$ & 90 & 38 & $6 \cdot 1$ & $48 \cdot 5$ & $78 \cdot 2$ & $0 \cdot 69$ & $11 \cdot 4$ & 0.63 & $12 \cdot 9$ \\
\hline 106. Sciatica & 31 & $70 \cdot 0$ & 94 & 37 & $5 \cdot 6$ & $54 \cdot 0$ & $85 \cdot 7$ & 0.63 & $11 \cdot 3$ & 0.61 & $12 \cdot 9$ \\
\hline 107. Sciatica & 42 & $65 \cdot 7$ & 95 & 36 & $5 \cdot 7$ & $\mathbf{5 3 \cdot 2}$ & $83 \cdot 1$ & 0.58 & $11 \cdot 0$ & 0.46 & $11 \cdot 5$ \\
\hline 108. Sciatica & 32 & $68 \cdot 0$ & 90 & 39 & $5 \cdot 6$ & $52 \cdot 3$ & $85 \cdot 7$ & $0 \cdot 68$ & $11 \cdot 8$ & 0.65 & $13 \cdot 6$ \\
\hline 109. Sciatica & 22 & $67 \cdot 2$ & 95 & 44 & $6 \cdot 1$ & 一 & - & - & - & $0 \cdot 63$ & $15 \cdot 1$ \\
\hline 110. Sciatica & 45 & $\mathbf{7 4 \cdot 3}$ & 95 & 43 & $5 \cdot 5$ & $49 \cdot 5$ & $86 \cdot 8$ & $0 \cdot 68$ & $11 \cdot 0$ & 0.66 & $12 \cdot 6$ \\
\hline 111. Sciatica & 25 & $60 \cdot 0$ & 98 & 44 & $5 \cdot 7$ & $43 \cdot 1$ & $77 \cdot 0$ & $0 \cdot 82$ & $13 \cdot 0$ & 0.66 & $15 \cdot 0$ \\
\hline 112. Sciatica & 38 & $64 \cdot 3$ & 95 & 40 & $5 \cdot 3$ & $40 \cdot 4$ & $67 \cdot 3$ & $0 \cdot 86$ & $13 \cdot 5$ & 0.60 & 14: 7 \\
\hline 113. Lumbago & 49 & $58 \cdot 6$ & 94 & 40 & $5 \cdot 5$ & - & - & - & - & 0.57 & $14 \cdot 2$ \\
\hline 114. Normal & 24 & $63 \cdot 0$ & 95 & 43 & $5 \cdot 6$ & $55 \cdot 6$ & $97 \cdot 5$ & 0.63 & $11 \cdot 7$ & $0 \cdot 62$ & $13 \cdot 6$ \\
\hline 115. Normal & 35 & $60 \cdot 0$ & 96. & 37 & $5 \cdot 6$ & - & - & - & - & 0.51 & $12 \cdot 5$ \\
\hline 116. Normal & 38 & $\mathbf{7 0 \cdot 0}$ & 90 & 43 & $\mathbf{5 \cdot 2}$ & - & - & - & - & $0 \cdot 68$ & $13 \cdot 7$ \\
\hline 117. Normal & 21 & $67 \cdot 0$ & 97 & 40 & $5 \cdot 5$ & $47 \cdot 3$ & $78 \cdot 8$ & $0 \cdot 69$ & 11.5 & 0.57 & $12 \cdot 5$ \\
\hline 118. Normal & 29 & $61 \cdot 4$ & 97 & 42 & $5 \cdot 4$ & $51 \cdot 3$ & $88 \cdot 4$ & 0.70 & $13 \cdot 3$ & 0.56 & $15 \cdot 0$ \\
\hline 119. Normal & 48 & $\mathbf{7 3 \cdot 0}$ & 95 & 42 & $5 \cdot 6$ & $43 \cdot 8$ & $75 \cdot 5$ & $0 \cdot 61$ & $9 \cdot 6$ & 0.44 & $9 \cdot 2$ \\
\hline 120. Fibrositis & 46 & $\mathbf{7 3 \cdot 0}$ & 92 & 39 & $5 \cdot 7$ & $42 \cdot 3$ & $69 \cdot 3$ & $0 \cdot 64$ & $10 \cdot 1$ & 0.40 & $9 \cdot 2$ \\
\hline 121. Fibrositis & 42 & $66 \cdot 0$ & 90 & 35 & $5 \cdot 7$ & $50 \cdot 7$ & $\mathbf{7 8 \cdot 0}$ & 0.66 & $11 \cdot 1$ & $0 \cdot 63$ & 12.9 \\
\hline $\begin{array}{l}\text { 122. Pleuro- } \\
\text { dynia }\end{array}$ & 33 & $55 \cdot 7$ & 89 & 41 & $6 \cdot 2$ & $45 \cdot 5$ & $77 \cdot 1$ & 0.73 & $11 \cdot 8$ & $0 \cdot 60$ & $12 \cdot 8$ \\
\hline Average & 37 & $65 \cdot 2$ & 91 & 40 & $5 \cdot 7$ & $48 \cdot 4$ & $\mathbf{7 9 \cdot 9}$ & $0 \cdot 69$ & $11 \cdot 7$ & 0.59 & $12 \cdot 3$ \\
\hline
\end{tabular}

Tabie IV.-SUbacute RheUmatism

\begin{tabular}{|c|c|c|c|c|c|c|c|c|c|c|c|}
\hline No.ofColumn : & 1 & 2 & 3 & 41 & 5 & 6 & 7 & 8 & 9 & 10 & 11 \\
\hline $\begin{array}{l}\text { 147. Female } \\
\text { 148. Female } \\
\text { 149. Female } \\
\text { 150. Female } \\
\text { 151. Female } \\
\text { 152. Female } \\
\text { 153. Male . } \\
\text { 154. Male . }\end{array}$ & $\begin{array}{l}24 \\
24 \\
19 \\
31 \\
33 \\
24 \\
27 \\
33\end{array}$ & \begin{tabular}{|l|}
$60 \cdot 0$ \\
$53 \cdot 0$ \\
$70 \cdot 0$ \\
$48 \cdot 6$ \\
$45 \cdot 7$ \\
$60 \cdot 0$ \\
$68 \cdot 6$ \\
$62 \cdot 0$
\end{tabular} & $\begin{array}{l}82 \\
88 \\
78 \\
84 \\
51 \\
76 \\
76 \\
50\end{array}$ & $\begin{array}{l}\mathbf{3 4} \\
\mathbf{3 6} \\
\mathbf{3 7} \\
\mathbf{3 6} \\
\mathbf{3 5} \\
\mathbf{3 6} \\
\mathbf{4 0} \\
\mathbf{3 6}\end{array}$ & $\begin{array}{l}\mathbf{5 \cdot 2} \\
5 \cdot 8 \\
5 \cdot 6 \\
5 \cdot 7 \\
5 \cdot 9 \\
5 \cdot 9 \\
5 \cdot 8 \\
6 \cdot 5\end{array}$ & \begin{tabular}{|l}
$55 \cdot 8$ \\
$\overline{53 \cdot 0}$ \\
$52 \cdot 3$ \\
- \\
$42 \cdot 5$ \\
$45 \cdot 0$ \\
$51 \cdot 0$
\end{tabular} & \begin{tabular}{c|}
$84 \cdot 5$ \\
- \\
$84 \cdot 1$ \\
$81 \cdot 7$ \\
$-\overline{66 \cdot 4}$ \\
$75 \cdot 0$ \\
$79 \cdot 7$
\end{tabular} & $\begin{array}{l}z \\
z \\
z \\
z \\
-\end{array}$ & $\begin{array}{l}- \\
z \\
z \\
z \\
-\end{array}$ & $\begin{array}{l}0.53 \\
0.59 \\
0.59 \\
0 \cdot 44 \\
0.37 \\
0.57 \\
0 \cdot 67 \\
0.59\end{array}$ & $\begin{array}{r}15 \cdot 0 \\
10 \cdot 5 \\
12 \cdot 2 \\
9 \cdot 3 \\
9 \cdot 2 \\
12 \cdot 1 \\
14 \cdot 9 \\
11 \cdot 5\end{array}$ \\
\hline
\end{tabular}


Table V.-Six Cases of Menopausal Periarticular Fibrositis

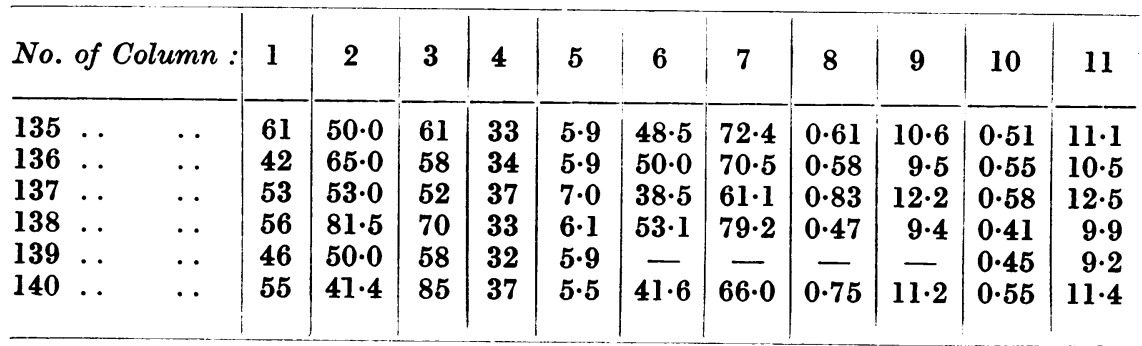

Table VI.-Six Cases of Osteo-Arthritis

\begin{tabular}{|c|c|c|c|c|c|c|c|c|c|c|c|}
\hline No. of Column : & 1 & 2 & 3 & 4 & 5 & 6 & 7 & 8 & 9 & 10 & 11 \\
\hline $\begin{array}{l}\text { 141. Female } \\
\text { 142. Female } \\
\text { 143. Female } \\
\text { 144. Male .. } \\
\text { 145. Male . } \\
\text { 146. Male .. }\end{array}$ & $\begin{array}{l}49 \\
38 \\
48 \\
46 \\
32 \\
60\end{array}$ & $\begin{array}{l}80 \cdot 0 \\
57 \cdot 2 \\
56 \cdot 0 \\
57 \cdot 2 \\
74 \cdot 0 \\
75 \cdot 0\end{array}$ & $\begin{array}{l}85 \\
89 \\
82 \\
94 \\
98 \\
78\end{array}$ & $\begin{array}{l}39 \\
42 \\
42 \\
47 \\
44 \\
39\end{array}$ & $\begin{array}{l}5 \cdot 9 \\
5 \cdot 8 \\
5 \cdot 9 \\
5 \cdot 8 \\
5 \cdot 6 \\
5 \cdot 8\end{array}$ & $\begin{array}{l}37 \cdot 0 \\
41 \cdot 4 \\
40 \cdot 0 \\
47 \cdot 9 \\
46 \cdot 1 \\
44 \cdot 4\end{array}$ & \begin{tabular}{l|}
$60 \cdot 7$ \\
$71 \cdot 4$ \\
$68 \cdot 9$ \\
$90 \cdot 5$ \\
$82 \cdot 3$ \\
$72 \cdot 8$
\end{tabular} & $\begin{array}{l}- \\
- \\
-\end{array}$ & $\begin{array}{l}- \\
- \\
-\end{array}$ & $\begin{array}{l}- \\
\text { - } \\
-\end{array}$ & $\begin{array}{l}- \\
- \\
-\end{array}$ \\
\hline
\end{tabular}

Table VII.-Finally, the Results of Seven Sub.Jects who Fainted duRING the Test, together with Those of One Case of Hepatic Cirrhosis, INCLUDED AS CONTROL (No. 134)

\begin{tabular}{|c|c|c|c|c|c|c|c|c|c|c|c|}
\hline No. of Column & 1 & 2 & 3 & 4 & 5 & 6 & 7 & 8 & 9 & 10 & 11 \\
\hline $\begin{array}{l}\text { 127. Male . } \\
\text { 128. Male .. } \\
\text { 129. Male .. } \\
\text { 130. Male . } \\
\text { 131. Male . } \\
\text { 132. Male . } \\
\text { 133. Female } \\
\text { 134. Female }\end{array}$ & $\begin{array}{l}25 \\
36 \\
20 \\
35 \\
27 \\
32 \\
37 \\
28\end{array}$ & $\begin{array}{l}61 \cdot 5 \\
54 \cdot 3 \\
73 \cdot 0 \\
75 \cdot 0 \\
53 \cdot 0 \\
68 \cdot 6 \\
51 \cdot 4 \\
48 \cdot 6\end{array}$ & $\begin{array}{l}\mathbf{9 2} \\
95 \\
95 \\
74 \\
77 \\
\mathbf{9 3} \\
\mathbf{6 6} \\
\mathbf{5 6}\end{array}$ & $\begin{array}{l}39 \\
38 \\
42 \\
36 \\
40 \\
44 \\
29 \\
24\end{array}$ & $\begin{array}{l}5 \cdot 8 \\
5 \cdot 2 \\
5 \cdot 5 \\
5 \cdot 9 \\
5 \cdot 9 \\
5 \cdot 3 \\
6 \cdot 5 \\
5 \cdot 6\end{array}$ & $\begin{array}{l}52 \cdot 0 \\
- \\
52 \cdot 6 \\
51 \cdot 2 \\
- \\
41 \cdot 9 \\
52 \cdot 1 \\
60 \cdot 2\end{array}$ & $\begin{array}{l}85 \cdot 2 \\
\overline{90 \cdot 7} \\
80 \cdot 0 \\
- \\
74 \cdot 8 \\
73 \cdot 5 \\
78 \cdot 7\end{array}$ & $\begin{array}{l}0.38 \\
- \\
0.47 \\
0.56 \\
-\overline{0} \\
0.61 \\
0.49 \\
0.21\end{array}$ & $\begin{array}{l}6 \cdot 0 \\
8 \cdot 2 \\
9 \cdot 8 \\
\overline{9 \cdot 4} \\
8 \cdot 7 \\
3 \cdot 9\end{array}$ & $\begin{array}{l}0 \cdot 41 \\
0 \cdot 41 \\
0 \cdot 39 \\
0 \cdot 47 \\
0 \cdot 39 \\
0 \cdot 38 \\
0 \cdot 38 \\
0 \cdot 13\end{array}$ & $\begin{array}{r}6 \cdot 8 \\
10 \cdot 0 \\
8 \cdot 2 \\
10 \cdot 3 \\
9 \cdot 5 \\
8 \cdot 3 \\
8 \cdot 5 \\
2 \cdot 8\end{array}$ \\
\hline
\end{tabular}

127, Lumbago; 128, 129, Sciatica; 130, Subacute rheumatism; 131, Anky losing spondylitis; 132, Gout; 133, Arthritis of knees.

\section{A. Hepatic Efficiency.}

\section{Analysis of Results}

As an example of the error involved by neglecting plasma volume in bromsulphalein testing, an article was found (Ezickson, 1939) in which the age and sex of the subjects were tabulated. The females from this table (p. 838) can be divided, taking the critical age as 45 years, into pre- and post-menopausal groups. The average dye retention in the younger group comes to $12 \cdot 1$ per cent., or little above 
the normal value, given as 10 per cent.; but that in the older group, averaging 21 per cent., is double what it should be. This age difference is not a measure of hepatic inefficiency, but is due to the fact that the increased body weight of post-menopausal obesity is unaccompanied by a proportional increase in plasma volume, and thus a greater concentration of dye was induced in the plasma of these cases.

A comparison of the hepatic indices in Tables I and II fails to show any significant difference between female control (averages 10.9 and 11.8$)$ and female rheumatoid subjects $(10.4$ and 11.4$)$. It may be concluded, therefore, that no abnormality of liver function detectable by this test, neither over- nor under-activity, is associated with rheumatoid arthritis. As regards other forms of chronic rheumatic disease: normal hepatic efficiency was found in subacute rheumatism (Table IV), in menopausal periarticular fibrositis (Table V), and also, using an earlier modification of the bromsulphalein test, in numerous cases of osteo-arthritis; but in the case of gout (occasional cases found normal) and ankylosing spondylitis (occasional cases found slightly below normal) insufficient material was tested for conclusions to be drawn. Only typical cases were selected; for instance, a marked rise of antistreptolysin titre was present in the sera of the subacute rheumatics.

The method is sensitive enough to reveal that the male control cases show more active liver function (Table III, averages 11.7 and 13.2) than the females. Moreover, the suitability of the test to detect a minor degree of liver dysfunction, had it been present, is further indicated by the results obtained in cases of syncope.

The occurrence of fainting when blood samples are drawn can be reduced to a rarity; but it cannot be abolished altogether, and is especially favoured by the sitting posture. In the first case of this kind it was noticed that the hepatic indices showed depression. It was found possible subsequently to encourage six further faints from suitable soil (e.g., by drawing attention to the blood entering the syringe). All were typical examples of vaso-vagal syndrome (Lewis, 1932), salivation, perspiration, pallor, nausea and bradycardia leading either to swimminess in the head or complete unconsciousness. The results are given in Table VII, where the average 4.75 minute index for the six males is seen to be 8.8 , as against an average control index (Table III) of 13.3. Thus the index of hepatic efficiency is depressed by temporary circulatory upset, which acts presumably by diminishing the flow of blood through the liver. No connection appears between the phenomenon of the delayed curve (twice displayed among the faint cases) and the occurrence of fainting, since hepatic function is not impaired in cases showing delay.

Although it was not considered necessary to verify the retention of dye in patients with known hepatic disease, one such case (134) is 
included at the end of Table VII for comparison with the fainters. The patient, a married woman aged 28 , previously healthy, had developed jaundice with pyrexia, somnolence, vomiting, dyspnœe, swelling of the feet and abdomen, and slight enlargement of liver and spleen three months before the bromsulphalein test was performed. Her galactose tolerance had been found moderately impaired two months after the onset. At the time of the test she was much better, eating well and walking about the ward, but her skin was still bronzed (though the scleræ were no longer tinged), and she had lost $1 \frac{1}{2}$ stone during her stay in bed. Three months later she returned home free from symptoms, the liver and spleen being still palpable. Her indices $(3.9$ and 2.8$)$ are much lower than those in the rest of the table.

\section{B. Plasma Volume.}

Two obvious facts emerge from the data in Tables I, II and III: first, that the average plasma volume in female control cases is only 4 per cent. below that of the male controls, a considerably smaller difference than that between their red cell volumes; and second, that there is gross abnormality in the plasma volumes of the rheumatoid arthritics. Other chronic rheumatic diseases gave normal results, shown for subacute rheumatism in Table IV, for menopausal periarticular fibrositis in Table V, and for osteo-arthritis in Table VI. Rough assessment, by an earlier method, showed the plasma volume in gout to be normal, but in ankylosing spondylitis to be increased to about the same degree as in rheumatoid arthritis. The well known tendency for age and obesity to lower the ratio between blood volume and body weight was observed in the present series, as it was in blood volume determinations by the Congo red method upon osteo-arthritics (Sparks and Haden, 1932). Care was taken to ensure that gold treatments were not affecting results.

If now the plasma volumes (expressed as $\mathrm{ml}$. per $\mathrm{kg}$.) in Table II are plotted against patients' weights (Fig. 2), red cell volumes (Fig. 3), plasma protein percentages (Fig. 4) and suspension stabilities (Fig. 5) a definite tendency to linear relationship (in spite of ectopic points) appears in Fig. 2 (weights), a similar tendency appears in Fig. 3 (red cell volumes), though rather limited to the more anæmic cases, a less definite tendency appears in Fig. 4 (plasma proteins), while no relationship is shown in Fig. 5 (suspension stabilities). Moreover, the straightline relationships suggested by the first three graphs are directed at or about the average values (marked by crosses) of the control cases, while the absence of linearity in the suspension stability graph is emphasised by the distance of the normal value from any conceivable line of relationship among the points.

Thus two inferences may be drawn: (a) that the increase in plasma volume observed is a true increase, since no other mechanism of over- 
dilution of dye in the blood stream (such as concentration at a septic focus) would run parallel to body weight and red cell volume; and (b) that four abnormalities (of plasma volume, plasma protein, red cell

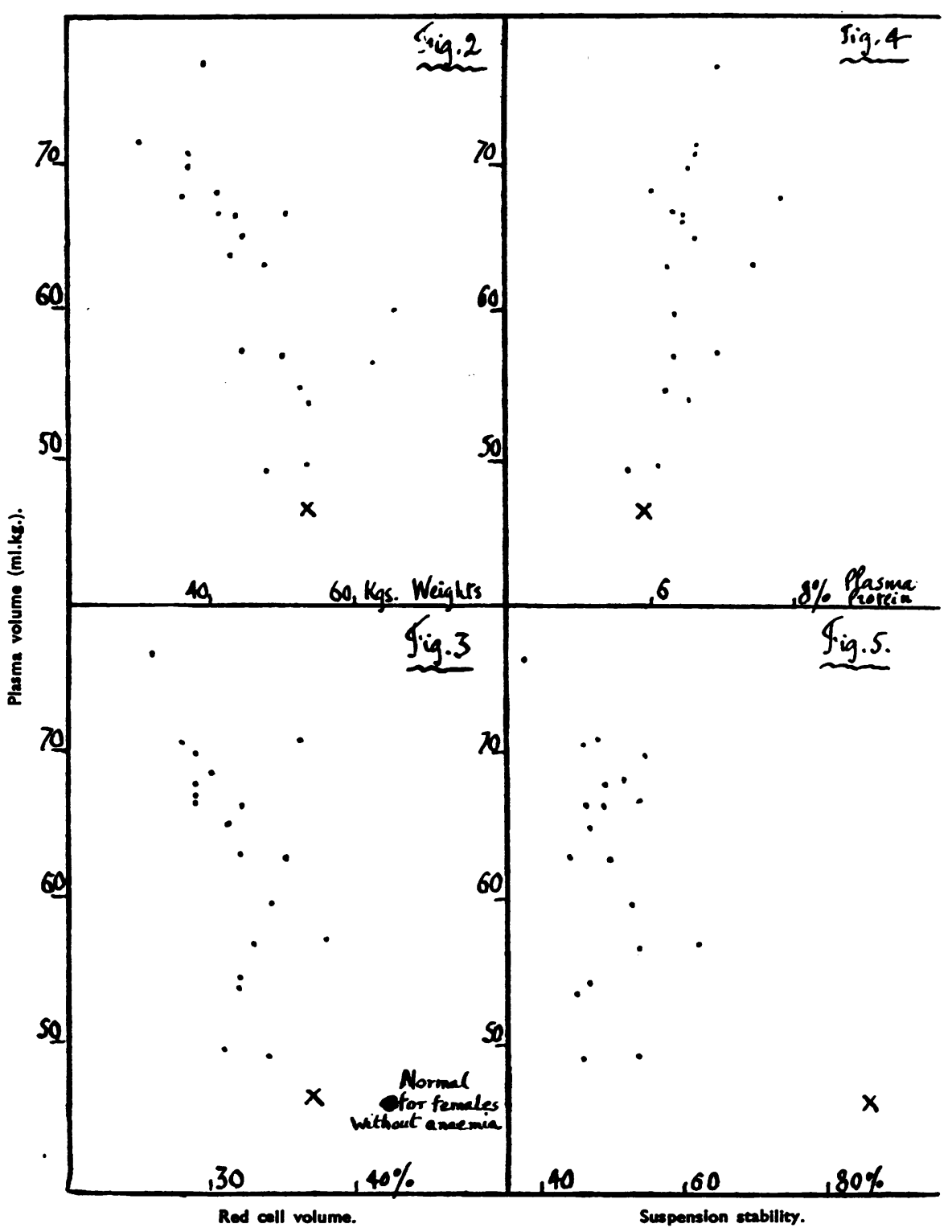

volume and body weight) occur in rheumatoid arthritis in association with each other, but distinct from the factor of suspension stability, forming a group of laboratory signs which might be called the " hydræmic syndrome." 
The fact that this syndrome is independent of suspension stability (the only sign generally held to reflect the arthritis itself) indicates that it plays only an incidental, and not an essential part in the disease. A direct comparison between the intensity of the syndrome and that of the accompanying joint disease is difficult to make. Since it is impossible to measure the activity of a multiple arthritis, where various joints of various sizes are in various stages of disease, the term "flaring up" tends to be used indiscriminately of the joint and the general condition, principal criteria being (together with pyrexia) the factors of anæmia and wasting, which form part of the hydræmic syndrome itself. However, when attention was focused solely upon the activity of the joints in the present series (pyrexia, pain and synovitis only being studied) a definite absence of relationship to the hydræmic syndrome was observed. Case 84 , for instance, was at the time of the test undergoing exceptionally severe activity in both hips; but she was plump, even healthy-looking, and her plasma volume is one of the lower values. Case 93 may be chosen as contrast to this picture, the suspension stability being practically the same and the anæmia rather less; here was a skeleton of a woman with enormously increased plasma volume whose joints crippled her so little that she was able to hop briskly around the building. Case 81 resembled Case 84 in having a nearly normal plasma volume, though her joint disease was less active; she was noted by the house physician as "of a healthy fat appearance with white skin," which again equates the degree of hydræmia with that of wasting, not that of arthritis. Indeed, the surest way of discovering clinically the probable presence of the hydræmic syndrome is by noting the degree of wasting of the interosseous muscles of the hands.

The normal plasma volume results obtained in menopausal periarticular fibrositis have a special suggestiveness. These patients are, as a rule, anything but wasted, there is no rise in plasma volume and seldom or slight in protein, though an isolated anæmia is usually present. The interesting possibility emerges that the absence of the hydræmic syndrome may be the actual factor of difference between this disease and rheumatoid arthritis; and consequently that the hydræmic syndrome in rheumatoid arthritis may be connected with an endocrine vector in the reverse direction to that of the menopause. In this connection it may be recalled that the thyroid gland in particular has been suspected of a part in rheumatism (Poynton and Schlesinger, 1931), and that points of similarity, rather striking in their diversity, exist between thyrotoxicosis and the "typical" acute rheumatoid arthritis of young women-namely, emaciation, nervous shock at onset, menstrual disorders, tachycardia, osteoporosis and diminished glucose tolerance. 


\section{Discussion of the Hydrcemic Syndrome.}

In order to make clear the magnitude of the abnormalities observed in rheumatoid arthritis, Table VIII, showing the reinforcement effect of the hydræmia upon the raised protein and its compensation effect upon the lowered red cell volume, has been compiled; total protein averages as much as 50 per cent. above, and total cells only 15 per cent. below, normal, thus reversing the usual order of importance assigned to these two factors in rheumatoid arthritis.

\begin{tabular}{|c|c|c|}
\hline \multicolumn{3}{|c|}{ TaBLE VIII } \\
\hline Cque No. & $\begin{array}{c}\text { Plasma Protein } \\
\text { in Grams per Kg. } \\
\text { Body Weight. }\end{array}$ & $\begin{array}{c}\text { Red Cell Volume } \\
\text { in Ml. per Kg. } \\
\text { Body Weight. }\end{array}$ \\
\hline 80 & $4 \cdot 54$ & $28 \cdot 6$ \\
\hline 81 & $3 \cdot 01$ & $22 \cdot 1$ \\
\hline 81 (later) & $3 \cdot 58$ & 28.0 \\
\hline 82 & $\mathbf{3} \cdot \mathbf{3 8}$ & $25 \cdot 7$ \\
\hline 83 & 4.09 & $29 \cdot 2$ \\
\hline 83 later) & $3 \cdot 95$ & $35 \cdot 0$ \\
\hline 84 & $3 \cdot 50$ & $25 \cdot 3$ \\
\hline 85 & $4 \cdot 26$ & $27 \cdot 2$ \\
\hline 86 & $2 \cdot 80$ & $25 \cdot 3$ \\
\hline 87 & $3 \cdot 76$ & $30 \cdot 8$ \\
\hline 89 & 3.91 & $34 \cdot 0$ \\
\hline 90 & $4 \cdot 25$ & $31 \cdot 2$ \\
\hline 92 & $4 \cdot 68$ & $29 \cdot 8$ \\
\hline 93 & $4 \cdot 67$ & $39 \cdot 8$ \\
\hline 94 & $5 \cdot 26$ & $26 \cdot 8$ \\
\hline 95 & $4 \cdot 29$ & $29 \cdot 2$ \\
\hline 96 & 4.21 & $27 \cdot 3$ \\
\hline 97 & $4 \cdot 69$ & $27 \cdot 6$ \\
\hline 98 & $5 \cdot 28$ & $27 \cdot 7$ \\
\hline Average & $4 \cdot 11$ & $29 \cdot 0$ \\
\hline Normal ${ }^{*}$ & $2 \cdot 73$ & 34.0 \\
\hline
\end{tabular}

In the present work, where the rheumatoid arthritics were carefully selected severe cases, a rise in plasma protein percentage has been constantly and not sporadically recorded. Perhaps the inclusion of such cases as menopausal periarticular fibrositis in many rheumatoid investigations may have fostered the idea of inconsistency in this finding. The fact that the Kjeldahl results given here are lower than accepted normality was not further pursued, since their uniformity rendered them valid for comparative purposes.

To pin down the raised plasma protein of rheumatoid arthritics as either cause or effect of raised plasma volume calls for more evidence than is available here. It is more probable that a primary rise in protein (due to sepsis, presence of foreign protein, absorption of exudate) would draw up the plasma volume after it than the reverse, and

* Taking normal plasma protein as 5.8 per cent., cell volume as 42 per cent., and plasma volume as $47 \mathrm{ml}$. $/ \mathrm{kg}$. 
this view was taken in what appears to be the only previous record of a hydræmic syndrome-namely, a fatal case of rheumatic fever (Bradley, 1938) in which repeated readings of rising plasma volume and sedimentation rate paralleled falling red cell volume, hæmoglobin and red cell count; and the conclusion was drawn that the hydræmia, possibly due to increase of fibrinogen and globulin, was responsible for the major part of the anæmia and also for the increased sedimentation rate.

The present results do not support the idea that sedimentation is directly influenced by plasma volume (Fig. 5); but they do not conflict with the idea that anæmia may be. The simplest explanation of the direction of the linear relationship towards the normal value in plotting red cell volumes against plasma volumes (Fig. 3) is that of dilution of red cells by excess plasma. Moreover, the average total red cell volume of the rheumatoid cases of Table II, as calculated in Table VIII, is within 15 per cent. of normal-i.e., about the same as that of the control cases of Table $I$.

The anæmia of all forms of chronic rheumatism has been described (Collins, 1935) as a hæmoglobin deficiency with a relatively insignificant fall in the red cell count, only 24 out of 75 female rheumatoid arthritics showing a red count below five million. These findings do not quite conform to those obtained here; for the average of the last hundred blood counts performed on female rheumatoid cases emerges as: hæmoglobin 74 per cent. (Haldane), colour index 0.84, red cells 4.4 million, and white cells (89 cases only) 7.7 thousand, the distribution of the colour indices being 0.663 for 8 cases below 60 per cent. hæmoglobin, 0.770 for 21 cases between 60 and 69 per cent. hæmoglobin, 0.829 for 35 cases between 70 and 79 per cent. hæmoglobin, 0.923 for 26 cases between 80 and 89 per cent. hæmoglobin, and 0.933 for 10 cases above 90 per cent. The cases were, of course, selected by the physicians from among the rheumatoid population of the hospital as those requiring blood counts; and a rather sluggish anæmia, intermediate between orthochromic and hypochromic, seems indicated.

The picture is similar to that of the anæmia of pregnancy, which has been described as an "oligocythæmia hypovolæmia " (Dieckmann and Wegner, 1934) with an increase in plasma volume (25 per cent.) and in total cell volume (20 per cent.). Total cell volume in the present series of rheumatoid arthritics, though not far from normal, was only twice raised above it (Table VIII). Further similarity exists in the raised fibrinogen level and lowered suspension stability of pregnancy.

\section{Recapitulation.}

The severe rheumatoid arthritis of young women may be divided into two syndromes-namely, (a) the essential impact of the disease 
upon the joints, and $(b)$ the hydræmic syndrome, in which the degree of loss of flesh, rise in plasma volume, rise in plasma protein and oligocythæmia run parallel to each other. It is further suggested that a considerable part of the anæmia is a mere dilution effect, though not on that account any the less effective as an anæmia; and that the hydræmia may be caused by the rise in blood protein which is so marked a feature of the disease. This rise in protein, together with the emaciation, is to be derived from the unknown "poison" of rheumatoid arthritis only via endocrine imbalance, whereas the effect of the poison upon the joints is direct, thus accounting for the observed independence of the hydræmic syndrome and the joint disease.

\section{SUMmary}

1. A spectrophotometric acetone extraction method is described for the determination of bromsulphalein in blood.

2. By this method, liver function has been found within normal limits in chronic rheumatic disease.

3. By the same method, plasma volumes of chronic rheumatics have been determined, with the disclosure of gross abnormality in rheumatoid arthritis.

4. Changes in plasma volume, plasma protein, body weight and red cell volume in rheumatoid arthritis have been found to vary roughly in proportion to one another.

5. These four factors are described as the "hydræmic syndrome," whose relation to the essential joint condition is discussed.

\section{REFERENCES}

Andrews, K. R., and MUether, R. O.: J. Lab. Clin. Med., 1941, 26, 675.

Bezançon, F., and Weil, M.: "A Survey of Chronic Rheumatic Diseases." Oxford Univ. Press, London, 1938.

Bradley, W. H.: "Proc. Int. Congress on Rheumatism and Hydrology." Headley Bros., London, 1938.

Counns, D. H.: Lancet, 1935, 229, 548.

Columns, D. H., Gibson, H. J., Race, J., and Salt, H. B.: Annals of the Rheumatic Diseases, 1939, 1, 333.

Direckmann, W. J., and Wegner, C. R.: Arch. Int. Med., 1934, 53, 188.

Ezickson, W. J.: J. Lab. Clin. Med., 1939, 24, 836.

Hench, P. S.: Medical Clinics of North America, July, 1940, 1209.

Hewch, P. S.: Arch. Int. Med., 1938, 61, 451 and 495.

LEwIS, T.: Brit. Med. J., 1932, 873.

Mrumer, S.: "Reports on Chronic Rheumatic Diseases," No. 1. H. K. Lewis and Co., London, 1935.

Poynton, F. J., and Schimsinger, B.: "Recent Advances in the Study of Rheumatism." J. and A. Churchill, London, 1931.

Rawls, W. B., Weiss, S., and Collins, V. L.: Ann. Int. Med., 1939, $12,1455$.

Rosenthal, S. M., and White, E. C.: J. Amer. Med. As8., 1925, 84, 1112.

Sparkes, M. I., and Haden, R. L.: Amer. J. Med. Sci., 1932, 184, 753.

Watson, A G.: "Proc. Conf. Rheumatic Diseases." Pitman Press, Bath, 1928. 